\title{
Diabetes Mellitus: Insights from Epidemiology, Biochemistry, Risk Factors, Diagnosis, Complications and Comprehensive Management
}

\author{
Saruar Alam ${ }^{1}$ (D), Md. Kamrul Hasan ${ }^{2,3}\left(\mathbb{D}\right.$, Sharif Neaz $^{2}$, Nazmul Hussain ${ }^{2}$, Md. Faruk Hossain ${ }^{4}$ (D) and \\ Tania Rahman $1, *$ (D) \\ 1 Department of Biochemistry and Molecular Biology, University of Dhaka, Dhaka 1000, Bangladesh; \\ alamsaruar3@gmail.com \\ 2 Department of Biochemistry and Molecular Biology, Tejgaon College, National University of Bangladesh, \\ Gazipur 1704, Bangladesh; kamrulhasanhridoy205@gmail.com (M.K.H.); sharifneaz@gmail.com (S.N.); \\ nazmulrobs@gmail.com (N.H.) \\ 3 Department of Public Health, School of Health and Life Sciences, North South University, Bashundhara, \\ Dhaka 1229, Bangladesh \\ 4 Department of Biological Sciences, St John's University, Queens, NY 11439, USA; farukbmb16@gmail.com \\ * Correspondence: tania.rahman@du.ac.bd; Tel.: +880-2-9661900-7670
}

check for

updates

Citation: Alam, S.; Hasan, M.K.;

Neaz, S.; Hussain, N.; Hossain, M.F.;

Rahman, T. Diabetes Mellitus:

Insights from Epidemiology,

Biochemistry, Risk Factors, Diagnosis, Complications and Comprehensive Management. Diabetology 2021, 2, 36-50. https://doi.org/10.3390/ diabetology2020004

Academic Editor: Peter Clifton

Received: 29 November 2020

Accepted: 23 March 2021

Published: 16 April 2021

Publisher's Note: MDPI stays neutral with regard to jurisdictional claims in published maps and institutional affiliations.

Copyright: (c) 2021 by the authors. Licensee MDPI, Basel, Switzerland. This article is an open access article distributed under the terms and conditions of the Creative Commons Attribution (CC BY) license (https:/ / creativecommons.org/licenses/by/ $4.0 /)$.

\begin{abstract}
Diabetes mellitus has become a serious and chronic metabolic disorder that results from a complex interaction of genetic and environmental factors, principally characterized by hyperglycemia, polyuria, and polyphagia. Uncontrolled high blood sugar can result in a host of diabetic complications. Prolonged diabetes leads to serious complications some of which are life-threatening. The prevalence of diabetes patients is rising at epidemic proportions throughout the world. Every year, a major portion of the annual health budget is spent on diabetes and related illnesses. Multiple risk factors are involved in the etiopathogenesis of the disease and turning the disease into an epidemic. Diabetes, for which there is no cure, apparently can be kept under control by maintaining self-care in daily living, effective diabetes education, with comprehensive improvements in knowledge, attitudes, skills, and management. In this review, we focused on the biochemical aspects of diabetes, risk factors including both environmental and genetic, disease complications, diagnosis, management, and currently available medications for the treatment of diabetes.
\end{abstract}

Keywords: diabetes mellitus; epidemiology; biochemistry; metabolic disorder; risk factors; diagnosis; complications; management of diabetes

\section{Introduction}

Diabetes mellitus (DM) is primarily characterized by high blood glucose levels (hyperglycemia), polydipsia, and polyphagia. DM is one of the most common metabolic disorders that is increasing at an alarming rate all over the world [1-3]. The number of patients with DM has quadrupled (from 108 million in 1980 to 422 million in 2014) within 34 years only, while the worldwide incidence of diabetes among adults over 18 years of age has risen to $8.5 \%$ (2014) from $4.7 \%$ (1980) [1]. The WHO estimates that diabetes will be the 7th primary cause of fatality by 2030 [2]. There are mainly four common types of DM. Type 1 DM (T1DM) is caused by the autoimmune annihilation of the pancreatic- $\beta$ cell with no insulin production [4]. This type is also called insulin-dependent diabetes mellitus (IDDM) [5,6]. This type of DM is seen in childhood and includes $5-10 \%$ of total diabetes patients [1]. The major type of diabetes is Type 2 DM (T2DM), which is caused due to insufficient production of insulin or desensitization of insulin receptors that precludes the entry of glucose into the cell [7,8]. The type is predominantly seen in 90-95\% of cases. There is another type of diabetes called gestational diabetes mellitus (GDM) that occurs only during pregnancy. GDM occurs in approximately 5-15\% of pregnant women varying in ethnicity 
and regions [1-3]. Multifarious factors including genetic defects, pancreatic obstruction, surgery, organ transplantation contribute to the onset of this type of diabetes [9]. In the case of 40-60\%, women having GDM can develop DM after 5-10 years of pregnancy. Impaired glucose tolerance is potent to be expressed as T2DM whereas uncontrolled diabetes is the potential threat for the onset of other diseases like cardiovascular disease (CVD), blindness, renal failure, neurological disorder, the imbalanced osmolality of blood, hypertension, peripheral neuropathy, and many other diseases [10-14]. Monogenic diabetes, which is often misdiagnosed as T1DM or T2DM is caused by a mutation in a single gene or a cluster of genes $[15,16]$. It is an autosomal-dominant disease and patients with this have varying signs, symptoms, and clinical courses. The two categories of monogenic diabetes are neonatal DM and familial DM (also known as maturity-onset diabetes of the young (MODY)) [17]. Neonatal DM which is usually developed before 6 months of age can be transient or permanent [18]. The development of familial DM commonly occurs from late childhood through early adulthood, although it has been diagnosed in adults in their 50s $[19,20]$. Mutations in genes encoding transcription factors are most common in familial DM. The most common form of familial DM is MODY3 [21]. Clinically, these patients generally have a family history of diabetes, are non-insulin-dependent, and have a low renal threshold for glucose [17]. At least 10 genes have been linked to familial DM, and more than 20 genes may cause neonatal diabetes. Table 1 lists genes that have been linked to familial DM as well as variations of neonatal DM. Diabetes can be treated and its complications can be reduced by maintaining diet, physical activity, and proper medication and by regular monitoring of the complications [15,16,22-25].

Table 1. Genes behind monogenic diabetes and their clinical features.

\begin{tabular}{|c|c|c|}
\hline Features of Diabetes & Gene Involved & Clinical Outcome \\
\hline \multirow{5}{*}{ MODY } & GCK [26] & $\begin{array}{l}\text { GCK-MODY; stable, nonprogressive, normally does not require } \\
\text { treatment. Microvascular complications developed in rare cases }\end{array}$ \\
\hline & HNF1A [27] & $\begin{array}{l}\text { HNF1A-MODY; progressive defect in insulin secretion, requires a low } \\
\text { dose of sulfonylurea therapy }\end{array}$ \\
\hline & HNF4A [28] & $\begin{array}{l}\text { HNF4A-MODY; progressive insulin secretory defect, sensitive to } \\
\text { sulfonylurea }\end{array}$ \\
\hline & HNF1B [29] & $\begin{array}{l}\text { HNF1B-MODY; atrophy of the pancreas, renal disease, hyperuricemia, } \\
\text { and gout may develop }\end{array}$ \\
\hline & Kir6.2 [30] & Requires high dose of sulfonylurea therapy \\
\hline \multirow{7}{*}{ Neonatal diabetes } & KCNJ11 [30] & $\begin{array}{l}\text { Maybe permanent or transient intrauterine growth restriction, delay } \\
\text { development, sensitive to sulfonylurea }\end{array}$ \\
\hline & INS [31] & Require insulin therapy \\
\hline & $\mathrm{ABCC} 8[32]$ & Sensitive to sulfonylurea therapy, in some cases delay development \\
\hline & 6q24 (PLAG1, HYMA1) [33] & $\begin{array}{l}\text { Transient in nature, intrauterine growth restriction, macroglossia; } \\
\text { umbilical hernia, treatment possible other than insulin }\end{array}$ \\
\hline & GATA6 [34] & $\begin{array}{l}\text { Pancreatic hypoplasia and exocrine insufficiency require } \\
\text { insulin therapy }\end{array}$ \\
\hline & EIF2AK3 [35] & Develop Wolcott-Rallison syndrome, requires insulin therapy \\
\hline & FOXP3 [36] & $\begin{array}{c}\text { Immunodysregulation, polyendocrinopathy, enteropathy X-linked } \\
\text { (IPEX) syndrome; autoimmune diabetes; autoimmune thyroid disease; } \\
\text { exfoliative dermatitis; insulin-requiring }\end{array}$ \\
\hline
\end{tabular}

\section{Epidemiology of Diabetes}

The disease burden related to diabetes is high and rising in every country, fueled by the global rise in the prevalence of obesity and unhealthy lifestyles. The latest estimates show a prevalence rate of $11.1 \%$ with diabetes in 2019 , expected to rise to $13 \%$ by 2045 in 
Northern America and Caribbean regions [37]. The prevalence rate is most pronounced in the Middle East and North African regions which are predicted to rise $13.9 \%$ by 2045 (Figure 1). The lowest prevalence rate (4.7\%) is observed in Africa which is expected to increase to 5.2\% in 2045 [37]. In general, countries in South-East Asia and South America have either high or intermediate incidences [37]. According to a recent study by Saeedi et al. in 2019 [37], a global prevalence of 463 million people with diabetes was recorded which represents a $9.3 \%$ prevalence rate worldwide. By 2030 this prevalence rate is estimated to reach $10.2 \%$ and by 2045 to $10.9 \%$. The region-stratified diabetes prevalence is calculated for several countries which display the countries with the highest number of diabetic patients in 2019, worldwide [38]. The top 10 countries or territories for the number of people with diabetes are identified (Figure 2). Among these countries, China has the highest proportion of diabetic patients at around 116 million. India seconds the list at 77 million followed by the United States of America at 31 million demonstrating the US as one of the most diabetic risk countries in the upcoming decade. Pakistan, Brazil, and Mexico are those projected to the high-end diabetic groups with diabetic patients at around 19 million, 16 million, and 12 million, respectively. While Bangladesh falls in the lower end of this list, the country's increasing population and lack of well-planned intervention strategies make it no lower diabetic risk than the US.

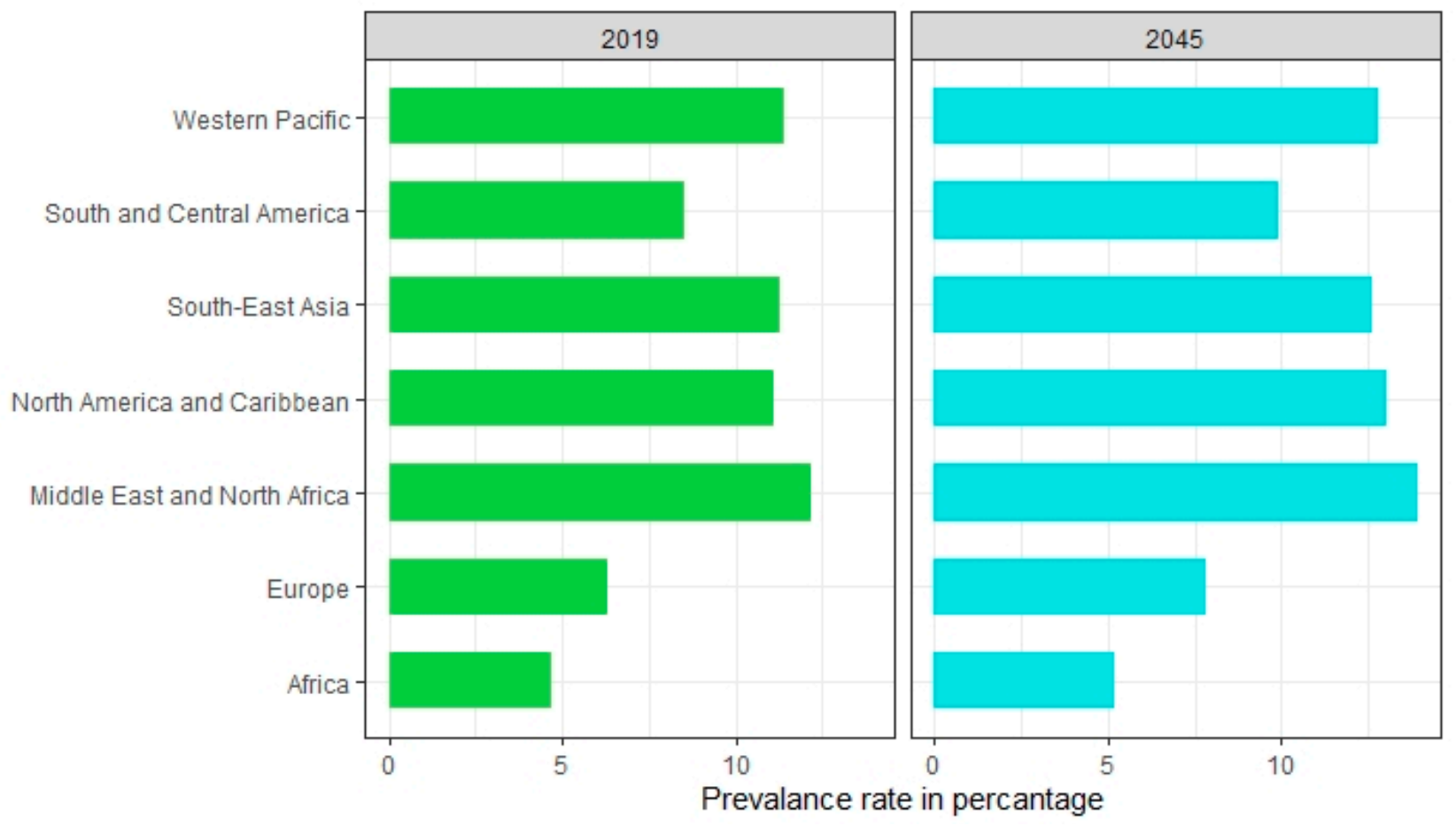

Figure 1. Prevalence of diabetes by world regions in 2019 and 2045 (estimated). 


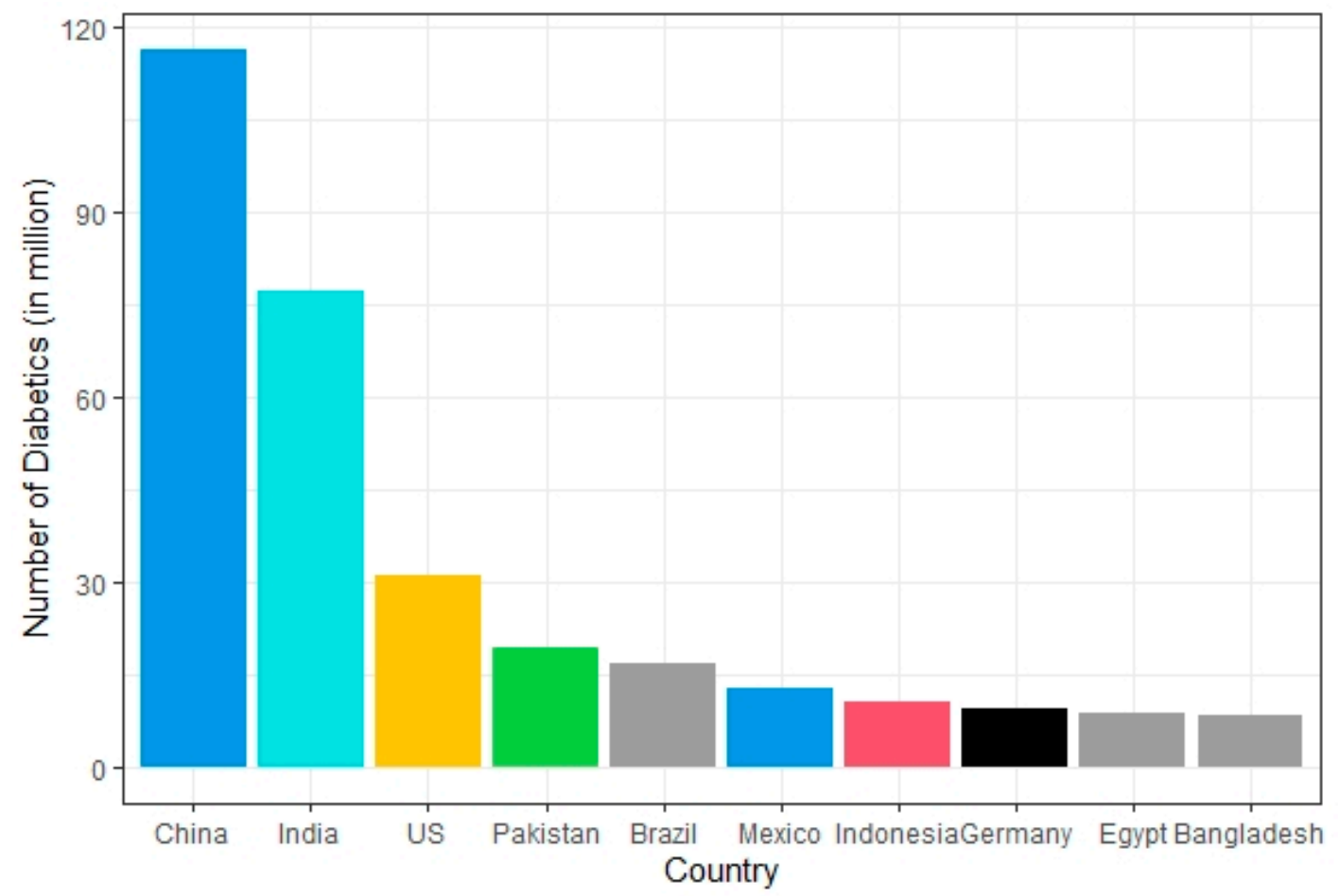

Figure 2. Countries with the highest number of diabetic patients worldwide in 2019.

\section{Risk Factors for Diabetes}

Globally, the prevalence of DM has increased and therefore has grown in severity as a public health problem. Multiple risk factors are involved in the actual onset of the disease. Genetics, atmosphere, loss of very first phase associated with insulin launch, sedentary way of life, lack of physical exercise, smoking, alcoholic beverages, dyslipidemia, reduced $\beta$-cell sensitivity, hyperinsulinemia, improved glucagon activity are the primary risk elements for prediabetes and DM [39-46]. These factors appear to play a significant role in insulin resistance or insulin nonfunctionality resulting in disease advancement. Based on WHO (2011), approximately $90 \%$ of patients develop T2DM, mostly related to excess body weight. Obstructive sleep apnea and sleep disorder that are seen among overweight adult individuals are a common risk factor for insulin resistance and glucose sensitivity which collectively progresses to prediabetes and then T2DM. The diet containing low fiber but a high glycemic index (GI) is thought to be positively related to the onset of diabetes [47,48]. There is evidence that free fatty acids are one important link between insulin resistance and T2DM. Soft drinks of which the most deleterious feature is the high fructose load and consequent metabolic effects on the liver can cause obesity and increase body mass index (BMI) that may lead to T2DM.

Excess weight increases the mass of adipose tissue together with elevated secretion of adipokines and resistins, dysregulation of which leads to the development of T2DM [48,49]. The association of hyperuricemia and the development of T2DM have been investigated in several studies. In subjects with hyperuricemia and insulin resistance, $\beta$ cell function is triggered from its compensatory state [50]. In another study, while comparing four study groups (control, T2DM: with and without obesity and T1DM), C-peptide levels were found to increase in patients who had T2DM and obesity. It appears that uric acid behavior is closely related to $\beta$ cell function [51]. In another follow-up study, it was found that high serum uric acid was associated with a higher risk of T2DM independent of obesity, dyslipidemia, and hypertension [52]. Nevertheless, uric acid plays a role in cytokine secretion and has been identified as a mediator of endothelial dysfunction and systemic inflammation [53]. In a study among the Chinese population, a positive association was found between plasma concentration of uric acid and the incidence of 
T2DM. The association was somewhat attenuated after adjustment for metabolic syndrome, suggesting that the association between hyperuricemia and diabetes was partly mediated through metabolic syndrome particularly insulin resistance.

It is shown by other studies that in the context of the complex cellular environment of metabolic syndrome which is associated with oxidative stress, antioxidant properties of uric acid might convert to a pro-oxidant state owing to reactive oxygen species (ROS) accumulation [54]. This may also lead to adverse effects on endothelial function and a proinflammatory response, both of which are known to be associated with new-onset of T2DM [55]. Various studies of others reported that there is a positive association between high serum uric acid level and diabetes [54-58], whereas another study by Barzilay et al. shows no association, and studies of $\mathrm{Hu}$ et al. show an inverse association between uric acid and T2DM [59].

Some classes of drugs (i.e., antipsychotics, diuretics, immune suppressants, betablockers) also can induce diabetes [60,61]. Immunoglobin E (IgE) and chymase interact with other risk factors and both put a positive impact on the release of protease from mast cells and act as significant risk factors for prediabetes [44]. ROS and reactive nitrogen species (RNS) which increase the oxidative stress level in the body also induce the development of vascular diseases and diabetes. Increased iron in blood makes an environment for the Fenton reaction and Haber-Weiss reaction $[62,63]$ which decreases the ability of antioxidants and detoxifying enzymes. Low expression of catalase and superoxide dismutase 2 (SOD2) makes pancreatic $\beta$-cells sensitive to oxidative stress and decreased expression of a transcription factor responsible for low insulin production [64]. In T1DM, the destruction of insulin-producing pancreatic $\beta$-cells is caused by an autoimmune reaction that is activated by T-lymphocytes reacting against $\beta$-cells. $\mathrm{CD} 4^{+}$helper $\mathrm{T}$ cells cause tissue injury by activating macrophages and $\mathrm{CD} 8^{+}$cytotoxic $\mathrm{T}$ cells destroy $\beta$-cells directly. CD8+ cytotoxic $\mathrm{T}$ cells also release cytokines and activate macrophages. This results in the pancreatic lesion and causes cellular necrosis and lymphocyte infiltration. Locally produced cytokines (i.e., interferon- $\gamma$ by T-cells, macrophage-mediated cytokines TNF- $\alpha$, IL- 1 ) in the pancreas can damage $\beta$-cells through apoptosis. In $80 \%$ of T1DM cases, glutamic acid decarboxylase (GAD) autoantibodies are developed within the pancreatic $\beta$-cells [65]. Several infectious diseases including coxsackievirus, nonenveloped linear single-stranded RNA virus, rotavirus, and cytomegalovirus also trigger autoimmunity to T1DM. A couple of pancreatic diseases occur due to MMR (measles, mumps, and rubella) which can contribute to the development of T1DM producing autoantibodies $[65,66]$. Thus, diabetes can occur due to a complex interaction among many different risk factors.

\section{Diagnosis of Diabetes}

As untreated DM can lead to serious complications, early diagnosis of diabetes may prevent serious consequences due to the illness. Primary symptoms of diabetes include high blood glucose levels over a prolonged period, frequent urination, increased thirst, and elevated hunger. Some biochemical tests are routinely carried out to make a diagnosis of prediabetes or diabetes. Glycosylated hemoglobin $(\mathrm{HbA} 1 \mathrm{c})$ and oral glucose tolerance tests (OGTT) are commonly demonstrated for screening diabetes. OGTT test measures how well body cells can absorb glucose after consuming a specific amount of sugar. Usually, the suspected individual is treated with $75 \mathrm{~g}$ glucose orally and the plasma glucose level is measured $2 \mathrm{~h}$ after ingestion. If the plasma glucose level is found $\geq 11.1 \mathrm{mmol} / \mathrm{L}$, then the individual is diagnosed as diabetic [63]. Fasting plasma glucose test is another reliable routine method for the diagnosis of diabetes. Diabetes patients usually have a fasting glucose level of $\geq 7.0 \mathrm{mmol} / \mathrm{L}$. If a person has a plasma glucose level $\geq 7.8 \mathrm{mmol} / \mathrm{L}$ after $2 \mathrm{~h}$ of ingesting $75 \mathrm{~g}$ glucose, then it is said that the person has impaired glucose tolerance [67]. $\mathrm{HbA1c}$ is also widely used as a diagnostic test for diabetes. Patients with T2DM have a glycosylated hemoglobin level of $\geq 48 \mathrm{mmol} / \mathrm{mol}$ ( $\geq 6.5$ DCCT\%) [68]. Random blood sugar monitoring is yet another prognostic marker for determining diabetes. 


\section{Complications of Diabetes}

Long-term exposure to DM shows many other complications of diabetes. Diabetic nephropathy, diabetic retinopathy is caused due to prolonged high blood sugar level over time. When the level of blood glucose is high for a long period, it can increase myo-inositol oxygenase (MIOX) enzyme activity and enhances myo-inositol catabolism. The enzymatic degradation of myo-inositol alters the activity of $\mathrm{Na}^{+} / \mathrm{K}^{+}$ATPase and phosphatidylinositol synthases, the very important molecules in the secondary signaling pathway [69]. Thus, high blood glucose levels due to DM results in diabetic nephropathy, retinopathy, neuropathy, and diabetic cataracts. In uncontrolled diabetes, the high blood glucose level in the delicate vessels of the retina increases osmotic pressure, and the vessels get leaked or rupture in some instances resulting in an impaired supply of blood to the retina. To compensate for the ruptured retinoid vessels, collateral blood vessels grow out of the retina and cause scar tissue to form resulting in impaired vision [70,71]. Uncontrolled diabetes can affect kidneys, damaging the basement of glomerular capillaries, disrupting protein crosslinking, and allowing proteins in the urine to leak through, a process known as diabetic nephropathy [72]. Ketoacidosis is common in diabetic patients due to the continuous production of ketone bodies [73]. Diabetic ketoacidosis (DKA) is a feature of insulin insufficiency rather than resistance, which characterizes T2DM. In a case report conducted in China, it was found that a 52-year-old diabetic patient had impulsive gas gangrene of the scrotum due to severe DKA [74]. The phenomenon is also known as Fournier's gangrene is a very rare condition whereas diabetes makes it more common. T1DM patients may develop obstructive pancreatitis because of inflammation in the pancreas, hyperplasia of the pancreatic duct gland resulting in obstructive pancreatitis [75]. Diabetic patients are also at risk of free radical associated damage which is higher in diabetic patients than that of normal leading to atherosclerosis, cardiovascular disease, and hypertension. Prevalence of coronary artery disease (CAD), heart disease, and sudden cardiac death are elevated in diabetic patients. The high blood glucose level in diabetic patients stimulates superoxide production by the Maillard reaction. Several studies indicated that cognitive dysfunction occurs in T2DM affecting intelligence, attention, memory, learning, and perception. Diabetes is also diagnosed as a potent risk factor for cancer because both share some common risk factors including age, sex, obesity, diet, smoking, and alcohol [14,76-81]. The contributing factor of cancer due to DM is that in T2DM the hepatic production of IGF binding protein becomes low and circulating IGF-1 becomes high. In T2DM, mTOR is overactivated which phosphorylates IRS-1 and attenuates the metabolic pathway of insulin signaling. In T2DM, IRS-2 is upregulated and this activates the mitogen-activated protein kinase (MAPK) pathway and enhances cell proliferation $[82,83]$. Other studies also indicated that different forms of cancer including liver cancer, pancreatic cancer, and non-Hodgkin's lymphoma are predominant in diabetic patients. Diabetes and chronic hepatitis $\mathrm{C}(\mathrm{CHC})$ alter the immune system concurrently. Diabetic $\mathrm{CHC}$ patients have an augmented risk of progression of cirrhosis and hepatocellular carcinoma [84,85]. T2DM also affects the blood magnesium level. High blood glucose level decreases tubular reabsorption of magnesium resulting in lower blood Mg [86]. Decreased Mg level in blood shows symptoms of many diseases caused by magnesium deficiency.

\section{Management of Diabetes}

It was thought that once a patient is diabetic, he/she is diabetic for a lifetime; however, DM can go into remission [87]. Diabetes can be controlled by changing diet, doing physical exercise, maintaining reasonable body weight, monitoring lipid profile, and having appropriate medication when necessary. Changing diet is effective in controlling diabetes. Taking low glycemic food, complex carbohydrate, protein, and polyunsaturated fatty acid (PUFA) and fiber can help to maintain normal blood sugar. Moderate exercise which decreases obesity helps lowering blood glucose levels through insulin-independent glucose transport into the muscle. GDM is a high-risk factor for the development of postpartum T2DM. Breastfeeding for $\geq 3$ months downgrades the risk of postpartum T2DM by an extent of 
$\geq 40 \%$. Evidence suggests that breastfeeding improves early postpartum glucose tolerance (PGT) [88]. During lactation, estrogen levels dwindle which results in improved glucose and lipid metabolism as well as fat distribution. In this way, lactation for a long time decreases the long-term postpartum risk of T2DM in women with GDM [89]. Medication is the last step in the management of diabetes. T1DM and 25-30\% T2DM diabetic patients need insulin $[5,6]$. An inappropriate insulin dosing can sometimes lead to hypoglycemia which is even more serious than hyperglycemia. To overcome this phenomenon often diabetic patients having insulin are advised to keep some sugar or chocolate with them. Vibration therapy may have a positive effect in treating patients with diabetic peripheral neuropathy (DPN) [90]. To reduce the risk of coronary heart diseases and atherosclerosis due to diabetes maintaining a lipid profile is important as it might result from diabetic dyslipidemia [91]. Antioxidant therapy is effective as it lowers plasma insulin and $\mathrm{HbA1c}$ level. Vitamin $C$ has the antioxidant capacity and $\beta$-carotene has been exhibited to reduce oxidative LDL and prevent atherosclerosis [16,22]. Physical activity has always been prioritized by physician's advice for DM's management and many studies have suggested them effective in not only diabetic management but also in reducing the risk of age-onset diabetes alongside other age-onset diseases including cardiovascular diseases [92-94]. Sedentary lifestyle is a critical risk factor of DM, especially via insulin resistance and evidence suggests that a healthy exercise routine reduces insulin resistance while also boosting cardiovascular health $[95,96]$. Aerobic exercise plays a vital role in reducing the risk of mortality rate in type 1 and type 2 diabetes [97]. Walking, cycling, jogging, and swimming are several examples of aerobic exercise [97]. Evidence also suggests that swimming can have a beneficial role for both normal diabetic and gestational diabetic (GDM) mothers, alongside drug therapies $[98,99]$. Wang et al. found that running at leisure time reduces the risk of developing type 2 diabetes by $28 \%$ [100]. Riiser et al. found that cycling as transportation is inversely associated with self-reported diabetes [101]. Alternatively, high-intensity interval training (HIIT) exalts insulin sensitivity and glycemic control in adults with type 2 diabetes [102].

There are some drugs that are often prescribed to treat T2DM (Table 2). The most commonly used drugs are a class of biguanides, thiazolidinediones, $\alpha$-glucosidase inhibitors, and glucagon-like peptide- 1 agonist. It is estimated that proton pump inhibitors have certain effects in managing diabetes [25]. The different classes of drugs work in a different way although all of these help to maintain normal blood glucose levels. Nevertheless, some of these drugs have some metabolic side effects. For example, TZDs have a well-defined set of side effects associated with their action as a PPAR-gamma agonist in adipocytes. Hence, the proper use of these drugs under prescription will exhibit a good impact in controlling diabetes [103].

In Table 2, seven classes of drugs are listed that have been utilized in pharmacological therapies of DM. These drugs are prescribed based on the etiological difference of diabetic patients, for example, insulin secretagogues increase insulin level which in insulin-resistant patients is not very effective and since they are only functional in the case of healthy $\beta$-cells [104], these drugs are not applicable for T1DM patients either. Insulin secretagogues are one of the earliest developed antidiabetic drugs and a major disadvantage of them is that there is always a chance of causing hypoglycemia. GLP-1 agonists which are the latest in the line of antidiabetic drugs can also increase insulin level without any risk of hypoglycemia and they are reported to be more potent than DPP4 inhibitors which perform by inhibiting the GLP-1 breakdown, also a major concerning issue of the DPP4 inhibitors is that they increase the risk of pancreatitis thus acting as a risk factor for pancreatic cancer if use is prolonged [105]. $\alpha$-glucosidase inhibitors act by lowering glucose absorption in the gastrointestinal region and their natural origin makes them less harmful than their synthetic counterparts [106], Unfortunately, their potency is also comparatively low and high doses can cause gastrointestinal irritations. SGLT-2 inhibitors, on the other hand, reduce blood glucose level by increasing glucose excretion in kidneys and some studies even suggest that SGLT2 inhibitors may have a renoprotective effect [107,108]. Biguanide (metformin) and 
Thiazolidinedione type drugs are most frequently used against insulin-resistant T2DM and in some cases, they are even used together in combination [109]. Speaking of combination drugs, metformin is reportedly the most commonly used antidiabetic combination drug, and it is used in combination with either $\alpha$-glucosidase inhibitors or GLP-1 agonists, SGLT2 inhibitors, DPP4 inhibitors, or thiazolidinedione depending on the patient's medical condition [110].

Table 2. Currently used drugs targeting different sites.

\begin{tabular}{|c|c|c|c|c|}
\hline Drug Class & Example & Mode of Action & Common Side Effects & References \\
\hline Insulin secretagogues & $\begin{array}{l}\text { Sulfonylureas } \\
\text { Meglitinides }\end{array}$ & $\begin{array}{l}\text { Inhibit } \beta \text {-cell } \mathrm{K}+\mathrm{ATP} \text { channel and } \\
\text { facilitate insulin secretion }\end{array}$ & $\begin{array}{l}\text { Hypoglycemia } \\
\text { Weight gain }\end{array}$ & {$[111]$} \\
\hline GLP-1 agonists & $\begin{array}{l}\text { Liraglutide } \\
\text { Exenatide } \\
\text { Lixisenatide }\end{array}$ & $\begin{array}{l}\text { Increase glucose-dependent insulin } \\
\text { secretion, reduces glucagon secretion, } \\
\text { and delays gastric emptying }\end{array}$ & Pancreatitis & {$[112,113]$} \\
\hline$\alpha$-glucosidase inhibitors & $\begin{array}{l}\text { Acarbose } \\
\text { Miglitol } \\
\text { Voglibose }\end{array}$ & $\begin{array}{l}\text { Reduces the rate of digestion of } \\
\text { carbohydrate in the intestine hence } \\
\text { less glucose absorption }\end{array}$ & $\begin{array}{l}\text { Abdominal pain } \\
\text { Diarrhea } \\
\text { Flatulence }\end{array}$ & {$[114]$} \\
\hline SGLT-2 inhibitors & $\begin{array}{l}\text { Canagliflozin } \\
\text { Dapagliflozin } \\
\text { Empagliflozin }\end{array}$ & Increases glucose excretion in urine & $\begin{array}{l}\text { Hypotension } \\
\text { Urinary tract infection }\end{array}$ & [115] \\
\hline DPP4 inhibitors & $\begin{array}{l}\text { Vildagliptin } \\
\text { Linagliptin } \\
\text { Saxagliptin } \\
\text { Sitagliptin }\end{array}$ & $\begin{array}{l}\text { Increases endogenous GLP-1 and } \\
\text { GIP levels }\end{array}$ & $\begin{array}{c}\text { Respiratory tract infection } \\
\text { Nasopharyngitis } \\
\text { Headache }\end{array}$ & {$[116,117]$} \\
\hline Biguanides & Metformin & $\begin{array}{l}\text { Activate AMPK, decreasing glucose } \\
\text { production and insulin resistance }\end{array}$ & $\begin{array}{l}\text { Lactic acidosis } \\
\text { Gastrointestinal irritation }\end{array}$ & {$[118]$} \\
\hline Thiazolidinediones & $\begin{array}{l}\text { Pioglitazone } \\
\text { Rosiglitazone }\end{array}$ & $\begin{array}{c}\text { Activate PPAR- } \gamma, \text { decreasing insulin } \\
\text { resistance }\end{array}$ & $\begin{array}{l}\text { Fluid retention } \\
\text { Weight gain }\end{array}$ & [119] \\
\hline
\end{tabular}

\section{Recent Technologies for Combating Diabetes}

The complex nature of diabetes makes it difficult to develop effective treatment strategies as the etiology of the disease can differ from patient to patient. A universal cure for the disease is highly sought after in studies of the etiology of diabetes, as the cure is hardly feasible.

In type 2 diabetes the inability of cells to intake glucose from the blood can be due to genetic mutations or desensitization of receptors which makes developing treatment strategies harder compared to type 1 patients. Unfortunately, recent studies propose that insulin therapy in type 1 patients can lead to developing type 2 diabetes due to desensitization [120], which makes it an important time for finding a cure or alternative treatment methods. Several treatments have been developed so far for diabetes, with a majority of them being focused on type 1 diabetes. As the most common etiology of type 1 diabetes is damaged or dysfunctional islets of Langerhans cells, various treatment methods prioritized reconstructing or inserting functional islets of Langerhans cells in the patient's body which will liberate the patient from needing external insulin and terminate any possibility of developing type 2 diabetes from type 1 and any other side effect of external insulin ingestion.

Advancement of stem cell technology has been a boon for researchers in developing a subsequent cure for type 1 diabetes [121]. Mesenchymal stem cell (MSC) therapy has shown considerable improvement in $\beta$-cell function in newly diagnosed type 1 diabetic patient while also showing considerable immunomodulatory effect [122-127]. Additionally, the pluripotent nature of embryonic stem cells (ESC) makes therapy using ESCs an appealing approach for treating type 1 diabetes [128,129]. Induced stem cell therapy could become a universal cure for type 1 diabetes if the technology can be made clinically available for general patients [130]. 
Other promising diabetic treatment methods include VEGF inhibitors [131], SGLT2 inhibitors [132], SiRNA therapy [133], miRNA therapy [134], phytochemicals [135], and somatic gene therapy. While VEGF inhibition is not an absolute cure for diabetes, it has shown considerable effect against Diabetic Macular Oedema (DMO) [131,136], on the other hand, SGLT2 is a major renal protein responsible for glucose reabsorption, so SGLT2 inhibitors reduce the symptoms and risk factors of diabetes by lowering blood glucose level via inhibiting the glucose reabsorption pathway in kidneys [132]. Several studies on SiRNA and MiRNA therapy have suggested to be impactful against diabetic nephropathy $[133,134]$ and delayed wound healing [137]. By concluding these factors it can be suggested that the combination of VEGF inhibitors, SGLT2 inhibitors, SiRNA therapy, MiRNA therapy could be an effective management strategy for diabetic patients alongside being a reference for developing novel treatment and management methods.

Since time immemorial, naturopathic therapies have been applied for a number of health ailments and in recent times scientists have gone back to nature to look for cures for various ailments [138]. Several studies have suggested several plants to carry antidiabetic properties too (e.g., Murraya koenigii, Allium sativum, Withania somnifera, Gymnema sylvestre, Allium cepa, Ferula foetida, etc.) [139-142]. The bioactive phytochemicals found in these plant species can be extracted for direct use as drug-like compounds, or pharmacological agents [143]. This traditional approach could offer a natural key to unlock a suitable cure for diabetes.

In the case of somatic gene therapy, studies suggest this technique to have a considerable affinity for treating both type 1 and type 2 diabetes. While ex-vivo somatic gene therapy generates efficient $\beta$-cells, thus treating insulin deficiency $[129,144]$, in-vivo somatic gene therapy prioritizes lowering blood glucose via generating both insulin $[145,146]$ and noninsulin genes [147-149] (Gck, PTG etc.). While sharing a somewhat common strategy with metformin therapy, most importantly it does not share the risk factors of metformin therapy [150]. Somatic gene therapy shares a common disadvantage with stem cell technology as both these technologies are in the development phase and thus unavailable for general clinical practice. However, it is expected that DM would become globally extinct while these technologies become available for the general public.

\section{Conclusions and Future Perspectives}

This review focused on the epidemiology of diabetes, the complications of diabetes, and the appropriate management of the disease. As diabetes has become a serious chronic illness, the number of diabetic patients is increasing at an alarming rate which makes it an important topic of research. The finding of the relationship between diabetes and genetics, environmental factors, ethnicity, and lifestyle could be very helpful for the future development of the management of the disease. Based on the current data, it can be concluded that changing lifestyle, doing sufficient physical exercise, maintaining body weight, controlling lipid profile, and minimizing glucose level are very effective. As uncontrolled diabetes could lead to serious complications, research focusing on the early detection of diabetes, developing various tools for understanding pancreatic $\beta$-cell destruction, developing targeted drugs are the appropriate steps to control the disease.

Author Contributions: Idea and Conceptualization: S.A., M.K.H., T.R.; Literature search: S.A., M.K.H., M.F.H., T.R.; Data analysis: S.A., N.H., M.F.H.; Original draft preparation: S.A., M.K.H., S.N., M.F.H.; Critical revision: T.R. All authors have read and agreed to the published version of the manuscript.

Funding: This research received no external funding.

Institutional Review Board Statement: Not applicable as the study does not involve humans or animals.

Informed Consent Statement: Not applicable as the study does not involve humans.

Data Availability Statement: Not applicable. 
Conflicts of Interest: The authors declare no conflict of interest.

\section{References}

1. World Health Organization (WHO). Global Report on Diabetes; WHO: Geneva, Switzerland, 2017. Available online: http://www. who.int/diabetes/global-report/en/ (accessed on 22 September 2018).

2. Mathers, C.D.; Loncar, D. Projections of global mortality and burden of disease from 2002 to 2030. PLoS Med. 2006,3 , e442. [CrossRef]

3. World Health Organization; International Diabetes Federation. Definition and Diagnosis of Diabetes Mellitus and Intermediate Hyperglycaemia: Report of a WHO/IDF Consultation; WHO: Geneva, Switzerland, 2006.

4. Morran, M.P.; Vonberg, A.; Khadra, A.; Pietropaolo, M. Immunogenetics of type 1 diabetes mellitus. Mol. Asp. Med. 2015, 42, 42-60. [CrossRef]

5. Martin, B.C.; Warram, J.H.; Krolewski, A.S.; Soeldner, J.S.; Kahn, C.R.; Bergman, R.N. Role of glucose and insulin resistance in development of type 2 diabetes mellitus: Results of a 25-year follow-up study. Lancet 1992, 340, 925-929. [CrossRef]

6. Tisch, R.; McDevitt, H. Insulin-dependent diabetes mellitus. Cell 1996, 85, 291-297. [CrossRef]

7. Reinehr, T. Type 2 diabetes mellitus in children and adolescents. World J. Diabetes 2013, 4, 270-281. [CrossRef]

8. Reaven, G.M. Insulin-independent diabetes mellitus: Metabolic characteristics. Metabolism 1980, 29, 445-454. [CrossRef]

9. Zimmet, P.; Alberti, K.G.M.M.; Shaw, J. Global and societal implications of the diabetes epidemic. Nat. Cell Biol. 2001, 414, 782-787. [CrossRef]

10. Mokdad, A.H.; Ford, E.S.; Bowman, B.A.; Dietz, W.H.; Vinicor, F.; Bales, V.S.; Marks, J.S. Prevalence of obesity, diabetes, and obesity-related health risk factors. JAMA 2003, 289, 76-79. [CrossRef] [PubMed]

11. Razmaria, A.A. Diabetic neuropathy. JAMA 2015, 314, 2202. [CrossRef] [PubMed]

12. Cahill, M.; Halley, A.; Codd, M.; O'Meara, N.; Firth, R.; Mooney, D.; Acheson, R.W. Prevalence of diabetic retinopathy in patients with diabetes mellitus diagnosed after the age of 70 years. Br. J. Ophthalmol. 1997, 81, 218-222. [CrossRef] [PubMed]

13. Giovannucci, E.; Harlan, D.M.; Archer, M.C.; Bergenstal, R.M.; Gapstur, S.M.; Habel, L.A.; Pollak, M.; Regensteiner, J.G.; Yee, D. Diabetes and cancer: A consensus report. Diabetes Care 2010, 33, 1674-1685. [CrossRef]

14. Aronson, D.; Edelman, E.R. Coronary artery disease and diabetes mellitus. Cardiol. Clin. 2014, 32, 439-455. [CrossRef]

15. Cholesterol Treatment Trialists Collaborators; Reith, C.; Staplin, N.; Herrington, N.G.; Stevens, R.; Emberson, J.; Haynes, R.; Mafham, M.; Armitage, J.; Cass, A.; et al. Efficacy of cholesterol-lowering therapy in 18,686 people with diabetes in 14 randomised trials of statins: A meta-analysis. Lancet 2008, 371, 117-125. [CrossRef]

16. Ceriello, A.; Testa, R. Antioxidant anti-inflammatory treatment in type 2 diabetes. Diabetes Care 2009, 32, S232-S236. [CrossRef] [PubMed]

17. Fajans, S.S.; Bell, G.I. MODY. Diabetes Care 2011, 34, 1878-1884. [CrossRef] [PubMed]

18. Lemelman, M.B.; Letourneau, L.; Greeley, S.A.W. Neonatal diabetes mellitus. Clin. Perinatol. 2018, 45, 41-59. [CrossRef] [PubMed]

19. Jali, M.V.; Kambar, S.; Jali, S.M.; Gowda, S. Familial early onset of type-2 diabetes mellitus and its complications. N. Am. J. Med. Sci. 2009, 1, 377-380. [PubMed]

20. Alyafei, F.; Soliman, A.; Alkhalaf, F.; Sabt, A.; De Sanctis, V.; Elsayed, N.; Waseef, R. Clinical and biochemical characteristics of familial type 1 diabetes mellitus (FT1DM) compared to non-familial type 1 DM (NFT1DM). Acta Bio Med. Atenei Parm. 2018, 89, 27-31.

21. Waterhouse, C.; Keilson, J. Cori cycle activity in man. J. Clin. Investig. 1969, 48, 2359-2366. [CrossRef]

22. Maritim, A.C.; Sanders, R.A.; Watkins, J.B., III. Diabetes, oxidative stress, and antioxidants: A review. J. Biochem. Mol. Toxicol. 2003, 17, 24-38. [CrossRef] [PubMed]

23. Marín-Peñalver, J.J.; Martín-Timón, I.; Sevillano-Collantes, C.; Del Cañizo-Gómez, F.J. Update on the treatment of type 2 diabetes mellitus. World J. Diabetes 2016, 7, 354-395. [CrossRef]

24. Kim, K.S.; Kim, S.K.; Sung, K.M.; Cho, Y.W.; Park, S.W. Management of type 2 diabetes mellitus in older adults. Diabetes Metab. J. 2012, 36, 336-344. [CrossRef] [PubMed]

25. Takebayashi, K.; Inukai, T. Effect of proton pump inhibitors on glycemic control in patients with diabetes. World J. Diabetes 2015, 6, 1122-1131. [CrossRef]

26. Velho, G.; Froguel, P.; Clement, K.; Pueyo, E.M.; Rakotoambinina, B.; Zouali, H.; Passa, P.; Cohen, D.; Robert, J.J. Primary pancreatic beta-cell secretory defect caused by mutations in glucokinase gene in kindreds of maturity onset diabetes of the young. Lancet 1992, 340, 444-448. [CrossRef]

27. Bellanné-Chantelot, C.; Carette, C.; Riveline, J.-P.; Valéro, R.; Gautier, J.-F.; Larger, E.; Reznik, Y.; Ducluzeau-Fieloux, P.; SolaGazagnes, A.; Hartemann-Heurtier, A.; et al. The type and the position of HNF1A mutation modulate age at diagnosis of diabetes in patients with maturity-onset diabetes of the young (MODY)-3. Diabetes 2007, 57, 503-508. [CrossRef] [PubMed]

28. Staník, J.; Dusatkova, P.; Cinek, O.; Valentínová, L.; Hučková, M.; Škopková, M.; Dusatkova, L.; Stanikova, D.; Pura, M.; Klimeš, I.; et al. De novo mutations of GCK, HNF1A and HNF4A may be more frequent in MODY than previously assumed. Diabetologia 2013, 57, 480-484. [CrossRef]

29. Haldorsen, I.S.; Vesterhus, M.; Rder, H.; Jensen, D.K.; Svik, O.; Molven, A.; Njlstad, P.R.; Ræder, H.; Søvik, O.; Njølstad, P.R. Lack of pancreatic body and tail inHNF1Bmutation carriers. Diabet. Med. 2008, 25, 782-787. [CrossRef] 
30. Sagen, J.V.; Raeder, H.; Hathout, E.; Shehadeh, N.; Gudmundsson, K.; Baevre, H.; Abuelo, D.; Phornphutkul, C.; Molnes, J.; Bell, G.I.; et al. Permanent neonatal diabetes due to mutations in KCNJ11 encoding Kir6.2: Patient characteristics and initial response to sulfonylurea therapy. Diabetes 2004, 53, 2713-2718. [CrossRef] [PubMed]

31. Støy, J.; Edghill, E.L.; Flanagan, S.E.; Ye, H.; Paz, V.P.; Pluzhnikov, A.; Below, J.E.; Hayes, M.G.; Cox, N.J.; Lipkind, G.M.; et al. Insulin gene mutations as a cause of permanent neonatal diabetes. Proc. Natl. Acad. Sci. USA 2007, 104, 15040-15044. [CrossRef]

32. Babenko, A.P.; Polak, M.; Cavé, H.; Busiah, K.; Czernichow, P.; Scharfmann, R.; Bryan, J.; Aguilar-Bryan, L.; Vaxillaire, M.; Froguel, P. Activating Mutations in theABCC8Gene in neonatal diabetes mellitus. N. Engl. J. Med. 2006, 355, 456-466. [CrossRef]

33. Naylor, R.N.; Greeley, S.A.W.; I Bell, G.; Philipson, L.H. Genetics and pathophysiology of neonatal diabetes mellitus. J. Diabetes Investig. 2011, 2, 158-169. [CrossRef] [PubMed]

34. Catli, G.; Abaci, A.; Flanagan, S.; De Franco, E.; Ellard, S.; Hattersley, A.; Guleryuz, H.; Bober, E. A novel GATA6 mutation leading to congenital heart defects and permanent neonatal diabetes: A case report. Diabetes Metab. 2013, 39, 370-374. [CrossRef]

35. Brickwood, S.; Bonthron, D.T.; Al-Gazali, I.L.; Piper, K.; Hearn, T.; Wilson, I.D.; Hanley, A.N. Wolcott-Rallison syndrome: Pathogenic insights into neonatal diabetes from new mutation and expression studies of EIF2AK. J. Med. Genet. 2003, 40, 685-689. [CrossRef]

36. Wildin, R.S.; Ramsdell, F.; Peake, J.; Faravelli, F.; Casanova, J.-L.; Buist, N.; Levy-Lahad, E.; Mazzella, M.; Goulet, O.; Perroni, L.; et al. X-linked neonatal diabetes mellitus, enteropathy and endocrinopathy syndrome is the human equivalent of mouse scurfy. Nat. Genet. 2001, 27, 18-20. [CrossRef] [PubMed]

37. Saeedi, P.; Petersohn, I.; Salpea, P.; Malanda, B.; Karuranga, S.; Unwin, N.; Colagiuri, S.; Guariguata, L.; Motala, A.A.; Ogurtsova, K.; et al. Global and regional diabetes prevalence estimates for 2019 and projections for 2030 and 2045: Results from the International Diabetes Federation Diabetes Atlas, 9th edition. Diabetes Res. Clin. Pract. 2019, 157, 107843. [CrossRef] [PubMed]

38. International Diabetes Federation, IDF Diabetes Atlas, 9th ed.; IDF: Brussels, Belgium, 2019.

39. Lee, I.-M.; Shiroma, E.J.; Lobelo, F.; Puska, P.; Blair, S.N.; Katzmarzyk, P.T. Effect of physical inactivity on major non-communicable diseases worldwide: An analysis of burden of disease and life expectancy. Lancet 2012, 380, 219-229. [CrossRef]

40. Knott, C.; Bell, S.; Britton, A. Alcohol consumption and the risk of type 2 diabetes: A systematic review and dose-response meta-analysis of more than 1.9 million individuals from 38 observational studies. Diabetes Care 2015, 38, 1804-1812. [CrossRef]

41. Akter, S.; Goto, A.; Mizoue, T. Smoking and the risk of type 2 diabetes in Japan: A systematic review and meta-analysis. J. Epidemiol. 2017, 27, 553-561. [CrossRef]

42. Danaei, G.; Finucane, M.M.; Lu, Y.; Singh, G.M.; Cowan, M.J.; Paciorek, C.J.; Lin, J.K.; Farzadfar, F.; Khang, Y.-H.; Stevens, A.G.; et al. National, regional, and global trends in fasting plasma glucose and diabetes prevalence since 1980: Systematic analysis of health examination surveys and epidemiological studies with 370 country-years and 2.7 million participants. Lancet 2011, 378 , 31-40. [CrossRef]

43. Cornier, M.-A.; Donahoo, W.T.; Pereira, R.; Gurevich, I.; Westergren, R.; Enerbäck, S.; Eckel, P.J.; Goalstone, M.L.; Hill, J.O.; Eckel, R.H.; et al. Insulin sensitivity determines the effectiveness of dietary macronutrient composition on weight loss in obese women. Obes. Res. 2005, 13, 703-709. [CrossRef] [PubMed]

44. Chen, L.; Chen, R.; Wang, H.; Liang, F. Mechanisms linking inflammation to insulin resistance. Int. J. Endocrinol. 2015, 2015, 1-9. [CrossRef]

45. Maj, M.; Ilhan, A.; Neziri, D.; Gärtner, W.; Berggård, T.; Attems, J.; Base, W.; Wagner, L. Age related changes in pancreatic beta cells: A putative extra-cerebral site of Alzheimer's pathology. World J. Diabetes 2011, 2, 49-53. [CrossRef] [PubMed]

46. Schulze, M.B.; Hoffmann, K.; E Manson, J.; Willett, W.C.; Meigs, J.B.; Weikert, C.; Heidemann, C.; A Colditz, G.; Hu, F.B. Dietary pattern, inflammation, and incidence of type 2 diabetes in women. Am. J. Clin. Nutr. 2005, 82, 675-684. [CrossRef]

47. Li, D.-W.; Lu, T.-F.; Hua, X.-W.; Dai, H.-J.; Cui, X.-L.; Zhang, J.-J.; Xia, Q. Risk factors for new onset diabetes mellitus after liver transplantation: A meta-analysis. World J. Gastroenterol. 2015, 21, 6329. [CrossRef] [PubMed]

48. Sears, B.; Perry, M. The role of fatty acids in insulin resistance. Lipids Health Dis. 2015, 14, 1-9. [CrossRef]

49. Hossain, M.; Faruque, M.O.; Kabir, G.; Hassan, N.; Sikdar, D.; Nahar, Q.; Ali, L. Association of serum TNF- $\alpha$ and IL-6 with insulin secretion and insulin resistance in IFG and IGT subjects in a Bangladeshi population. Int. J. Diabetes Mellit. 2010, 2, 165-168. [CrossRef]

50. Jia, S.-D.; Wang, Y.-G.; Li, J. An analysis of islet beta-cell function in hyperuricemia. Zhonghua Nei Ke Za Zhi 2006, 45, 456-458.

51. Lytvyn, Y.; Perkins, B.A.; Cherney, D.Z. Uric acid as a biomarker and a therapeutic target in diabetes. Can. J. Diabetes 2015, 39, 239-246. [CrossRef] [PubMed]

52. Dehghan, A.; Van Hoek, M.; Sijbrands, E.J.; Hofman, A.; Witteman, J.C. High serum uric acid as a novel risk factor for type 2 diabetes. Diabetes Care 2007, 31,361-362. [CrossRef]

53. Kanellis, J.; Kang, D.-H. Uric acid as a mediator of endothelial dysfunction, inflammation, and vascular disease. Semin. Nephrol. 2005, 25, 39-42. [CrossRef]

54. Pradhan, A.D.; Manson, J.E.; Rifai, N.; Buring, J.E.; Ridker, P.M. C-reactive protein, interleukin 6, and risk of developing type 2 diabetes mellitus. JAMA 2001, 286, 327-334. [CrossRef]

55. Nabipour, I.; Vahdat, K.; Jafari, S.; Pazoki, R. Concurrent increased high sensitivity C-reactive protein and chronic infections are associated with coronary artery disease: A population-based study. Indian J. Med. Sci. 2007, 61, 135-143. [CrossRef]

56. Hayden, M.R.; Tyagi, S.C. Uric acid: A new look at an old risk marker for cardiovascular disease, metabolic syndrome, and type 2 diabetes mellitus: The urate redox shuttle. Nutr. Metab. 2004, 1, 10. [CrossRef] 
57. Thorand, B.; Baumert, J.; Chambless, L.; Meisinger, C.; Kolb, H.; Döring, A.; Löwel, H.; Koenig, W. Elevated markers of endothelial dysfunction predict type 2 diabetes mellitus in middle-aged men and women from the general population. Arter. Thromb. Vasc. Biol. 2006, 26, 398-405. [CrossRef] [PubMed]

58. Trayhurn, P.; Beattie, J.H. Physiological role of adipose tissue: White adipose tissue as an endocrine and secretory organ. Proc. Nutr. Soc. 2001, 60, 329-339. [CrossRef] [PubMed]

59. Hu, F.B.; Meigs, J.B.; Li, T.Y.; Rifai, N.; Manson, J.E. Inflammatory markers and risk of developing type 2 diabetes in women. Diabetes 2004, 53, 693-700. [CrossRef]

60. Penfornis, A.; Kury-Paulin, S. Immunosuppressive drug-induced diabetes. Diabetes Metab. 2006, 32, 539-546. [CrossRef]

61. Fathallah, N.; Slim, R.; Larif, S.; Hmouda, H.; Ben Salem, C. Drug-induced hyperglycaemia and diabetes. Drug Saf. 2015, 38, 1153-1168. [CrossRef] [PubMed]

62. Papanikolaou, G.; Pantopoulos, K. Iron metabolism and toxicity. Toxicol. Appl. Pharmacol. 2005, 202, 199-211. [CrossRef]

63. Vijan, S. Type 2 diabetes. Ann. Intern. Med. 2010, 152, ITC3-1. [CrossRef]

64. Simcox, J.A.; McClain, D.A. Iron and diabetes risk. Cell Metab. 2013, 17, 329-341. [CrossRef]

65. Atkinson, M.A. The pathogenesis and natural history of type 1 diabetes. Cold Spring Harb. Perspect. Med. 2012, 2, a007641. [CrossRef] [PubMed]

66. Atkinson, M.A.; Von Herrath, M.; Powers, A.C.; Clare-Salzler, M. Current concepts on the pathogenesis of type 1 diabetesConsiderations for attempts to prevent and reverse the disease. Diabetes Care 2015, 38, 979-988. [CrossRef] [PubMed]

67. Siu, A.L.; US Preventive Services Task Force. Screening for abnormal blood glucose and type 2 diabetes mellitus: U.S. Preventive Services Task Force recommendation statement. Ann. Intern. Med. 2015, 163, 861-868. [CrossRef] [PubMed]

68. American Diabetes Association. Summary of revisions for the 2010 clinical practice recommendations. Diabetes Care 2009, 33, S3. [CrossRef]

69. Yang, B.; Hodgkinson, A.; Millward, B.A.; Demaine, A.G. High glucose-induced DNA-binding activities of nuclear factor of activated $\mathrm{T}$ cells 5 and carbohydrate response element binding protein to the myo-inositol oxygenase gene are inhibited by sorbinil in peripheral blood mononuclear cells from patients with type 1 diabetes mellitus and nephropathy. Int. J. Diabetes Mellit. 2010, 2, 169-174. [CrossRef]

70. Tarr, J.M.; Kaul, K.; Chopra, M.; Kohner, E.M.; Chibber, R. Pathophysiology of diabetic retinopathy. ISRN Ophthalmol. 2013, 2013, 1-13. [CrossRef]

71. Antonetti, D.A.; Klein, R.; Gardner, T.W. Diabetic retinopathy. N. Engl. J. Med. 2012, 366, 1227-1239. [CrossRef]

72. Lim, A.K. Diabetic nephropathy-Complications and treatment. Int. J. Nephrol. Renov. Dis. 2014, 7, 361-381. [CrossRef]

73. Onyiriuka, A.N.; Ifebi, E. Ketoacidosis at diagnosis of type 1 diabetes in children and adolescents: Frequency and clinical characteristics. J. Diabetes Metab. Disord. 2013, 12, 47. [CrossRef]

74. Zhang, C.; Ma, L.; Peng, F.; Wu, Y.; Chen, Y.; Zhan, Y.; Zhang, X. Spontaneous gas gangrene of the scrotum in patient with severe diabetic ketoacidosis. Int. J. Diabetes Mellit. 2010, 2, 196-198. [CrossRef]

75. Moin, A.S.M.; Butler, P.C.; Butler, A.E. Increased proliferation of the pancreatic duct gland compartment in type 1 diabetes. J. Clin. Endocrinol. Metab. 2016, 102, 200-209. [CrossRef] [PubMed]

76. Satija, A.; Spiegelman, D.; Giovannucci, E.; Hu, F.B. Type 2 diabetes and risk of cancer. BMJ 2014, 350, g7707. [CrossRef]

77. Shah, A.D.; Langenberg, C.; Rapsomaniki, E.; Denaxas, S.; Pujades-Rodriguez, M.; Gale, C.P.; Deanfield, J.; Smeeth, L.; Timmis, A.; Hemingway, H. Type 2 diabetes and incidence of cardiovascular diseases: A cohort study in 1.9 million people. Lancet Diabetes Endocrinol. 2015, 3, 105-113. [CrossRef]

78. Zoungas, S.; Arima, H.; Gerstein, H.C.; Holman, R.R.; Woodward, M.; Reaven, P.; A Hayward, R.; Craven, T.; Coleman, R.L.; Chalmers, J. Effects of intensive glucose control on microvascular outcomes in patients with type 2 diabetes: A meta-analysis of individual participant data from randomised controlled trials. Lancet Diabetes Endocrinol. 2017, 5, 431-437. [CrossRef]

79. Leon, B.M. Diabetes and cardiovascular disease: Epidemiology, biological mechanisms, treatment recommendations and future research. World J. Diabetes 2015, 6, 1246-1258. [CrossRef]

80. Marseglia, A.; Fratiglioni, L.; Laukka, E.J.; Santoni, G.; Pedersen, N.L.; Bäckman, L.; Xu, W. Early cognitive deficits in type 2 diabetes: A POPULATION-based study. J. Alzheimer's Dis. 2016, 53, 1069-1078. [CrossRef]

81. Wojciechowska, J.; Krajewski, W.; Bolanowski, M.; Kręcicki, T.; Zatoński, T. Diabetes and cancer: A review of current knowledge. Exp. Clin. Endocrinol. Diabetes 2016, 124, 263-275. [CrossRef]

82. Denduluri, S.K.; Idowu, O.; Wang, Z.; Liao, Z.; Yan, Z.; Mohammed, M.K.; Ye, J.; Wei, Q.; Wang, J.; Zhao, L.; et al. Insulin-like growth factor (IGF) signaling in tumorigenesis and the development of cancer drug resistance. Genes Dis. 2015, 2, 13-25. [CrossRef]

83. Laplante, M.; Sabatini, D.M. mTOR signaling in growth control and disease. Cell 2012, 149, 274-293. [CrossRef]

84. Vigneri, P.; Frasca, F.; Sciacca, L.; Pandini, G.; Vigneri, R. Diabetes and cancer. Endocr. Relat. Cancer 2009, 16, 1103-1123. [CrossRef] [PubMed]

85. Antonelli, A. Hepatitis C virus infection and type 1 and type 2 diabetes mellitus. World J. Diabetes 2014, 5, 586-600. [CrossRef]

86. Barbagallo, M. Magnesium and type 2 diabetes. World J. Diabetes 2015, 6, 1152-1157. [CrossRef] [PubMed]

87. Panunzi, S.; Carlsson, L.M.S.; De Gaetano, A.; Peltonen, M.; Rice, T.; Sjöström, L.; Mingrone, G.; Dixon, J.B. Determinants of diabetes remission and glycemic control after bariatric surgery. Diabetes Care 2016, 39, 166-174. [CrossRef] 
88. Ziegler, A.-G.; Wallner, M.; Kaiser, I.; Rossbauer, M.; Harsunen, M.H.; Lachmann, L.; Maier, J.; Winkler, C.; Hummel, S. Long-term protective effect of lactation on the development of type 2 diabetes in women with recent gestational diabetes mellitus. Diabetes 2012, 61, 3167-3171. [CrossRef] [PubMed]

89. Hong, J.; Barnes, M.; Kessler, N. Case study: Use of vibration therapy in the treatment of diabetic peripheral small fiber neuropathy. J. Bodyw. Mov. Ther. 2013, 17, 235-238. [CrossRef] [PubMed]

90. Hong, J.; Barnes, M.J.; Kessler, N.J. Case study: Use of vibration therapy in the treatment of diabetic peripheral small fiber neuropathy. Int. J. Diabetes Mellit. 2015, 3, 72-75. [CrossRef]

91. Verma, S.; Hussain, M.E. Obesity and diabetes: An update. Diabetes Metab. Syndr. Clin. Res. Rev. 2017, 11, 73-79. [CrossRef]

92. Ruegsegger, G.N.; Booth, F.W. Health benefits of exercise. Cold Spring Harb. Perspect. Med. 2017, 8, a029694. [CrossRef]

93. Rasmussen, M.G.; Grøntved, A.; Blond, K.; Overvad, K.; Tjønneland, A.; Jensen, M.K.; Østergaard, L. Associations between recreational and commuter cycling, changes in cycling, and type 2 diabetes risk: A cohort study of Danish men and women. PLoS Med. 2016, 13, e1002076. [CrossRef] [PubMed]

94. Riddell, M.C.; Gallen, I.W.; Smart, E.C.; Taplin, E.C.; Adolfsson, P.; Lumb, A.N.; Kowalski, A.; Rabasa-Lhoret, R.; McCrimmon, R.J.; Hume, C.; et al. Exercise management in type 1 diabetes: A consensus statement. Lancet Diabetes Endocrinol. 2017, 5, 377-390. [CrossRef]

95. Kumar, A.S.; Maiya, A.G.; Shastry, B.; Vaishali, K.; Ravishankar, N.; Hazari, A.; Gundmi, S.; Jadhav, R. Exercise and insulin resistance in type 2 diabetes mellitus: A systematic review and meta-analysis. Ann. Phys. Rehabil. Med. 2019, 62, 98-103. [CrossRef] [PubMed]

96. Carbone, S.; Del Buono, M.G.; Ozemek, C.; Lavie, C.J. Obesity, risk of diabetes and role of physical activity, exercise training and cardiorespiratory fitness. Prog. Cardiovasc. Dis. 2019, 62, 327-333. [CrossRef] [PubMed]

97. Colberg, S.R.; Sigal, R.J.; Yardley, J.E.; Riddell, M.C.; Dunstan, D.W.; Dempsey, P.C.; Horton, E.S.; Castorino, K.; Tate, D.F. Physical activity/exercise and diabetes: A position statement of the American Diabetes Association. Diabetes Care 2016, 39, 2065-2079. [CrossRef] [PubMed]

98. Huang, L.; Yue, P.; Wu, X.; Yu, T.; Wang, Y.; Zhou, J.; Kong, D.; Chen, K. Combined intervention of swimming plus metformin ameliorates the insulin resistance and impaired lipid metabolism in murine gestational diabetes mellitus. PLoS ONE 2018, 13, e0195609. [CrossRef]

99. Ghiasi, R.; Naderi, R.; Sheervalilou, R.; Alipour, M.R. Swimming training by affecting the pancreatic Sirtuin1 (SIRT1) and oxidative stress, improves insulin sensitivity in diabetic male rats. Horm. Mol. Biol. Clin. Investig. 2019, 40, 1-12. [CrossRef]

100. Wang, Y.; Lee, D.-C.; Brellenthin, A.G.; Eijsvogels, T.M.; Sui, X.; Church, T.S.; Lavie, C.J.; Blair, S.N. Leisure-time running reduces the risk of incident type 2 diabetes. Am. J. Med. 2019, 132, 1225-1232. [CrossRef]

101. Riiser, A.; Solbraa, A.; Jenum, A.K.; Birkeland, K.I.; Andersen, L.B. Cycling and walking for transport and their associations with diabetes and risk factors for cardiovascular disease. J. Transp. Health 2018, 11, 193-201. [CrossRef]

102. Jelleyman, C.; Yates, T.L.; O’Donovan, G.; Gray, L.J.; King, J.A.; Khunti, K.; Davies, M.J. The effects of high-intensity interval training on glucose regulation and insulin resistance: A meta-analysis. Obes. Rev. 2015, 16, 942-961. [CrossRef]

103. Lai, S.-W.; Chen, P.-C.; Liao, K.-F.; Muo, C.-H.; Lin, C.-C.; Sung, F.-C. Risk of hepatocellular carcinoma in diabetic patients and risk reduction associated with anti-diabetic therapy: A population-based cohort study. Am. J. Gastroenterol. 2012, 107, 46-52. [CrossRef]

104. Raptis, S.A.; Dimitriadis, G.D. Oral hypoglycemic agents: Insulin secretagogues, $\alpha$-glucosidase inhibitors and insulin sensitizers. Exp. Clin. Endocrinol. Diabetes 2001, 109, S265-S287. [CrossRef]

105. Zhang, Z.; Chen, X.; Lu, P.; Zhang, J.; Xu, Y.; He, W.; Li, M.; Zhang, S.; Jia, J.; Shao, S.; et al. Incretin-based agents in type 2 diabetic patients at cardiovascular risk: Compare the effect of GLP-1 agonists and DPP-4 inhibitors on cardiovascular and pancreatic outcomes. Cardiovasc. Diabetol. 2017, 16, 31. [CrossRef] [PubMed]

106. Yin, Z.; Zhang, W.; Feng, F.; Zhang, Y.; Kang, W. $\alpha$-Glucosidase inhibitors isolated from medicinal plants. Food Sci. Hum. Wellness 2014, 3, 136-174. [CrossRef]

107. El Mouhayyar, C.; Riachy, R.; Khalil, A.B.; Eid, A.; Azar, S. SGLT2 inhibitors, GLP-1 agonists, and DPP-4 inhibitors in diabetes and microvascular complications: A review. Int. J. Endocrinol. 2020, 2020, 1762164. [CrossRef] [PubMed]

108. Margonato, D.; Galati, G.; Mazzetti, S.; Cannistraci, R.; Perseghin, G.; Margonato, A.; Mortara, A. Renal protection: A leading mechanism for cardiovascular benefit in patients treated with SGLT2 inhibitors. Heart Fail. Rev. 2021, 26, 337-345. [CrossRef]

109. Strowig, S.M.; Raskin, P. Combination therapy using metformin or thiazolidinediones and insulin in the treatment of diabetes mellitus. Diabetes Obes. Metab. 2004, 7, 633-641. [CrossRef]

110. Maruthur, N.M.; Tseng, E.; Hutfless, S.; Wilson, L.M.; Suarez-Cuervo, C.; Berger, Z.; Chu, Y.; Iyoha, E.; Segal, J.B.; Bolen, S. Diabetes medications as monotherapy or metformin-based combination therapy for type 2 diabetes. Ann. Intern. Med. 2016, 164, 740-751. [CrossRef]

111. Type 2 diabetes and insulin secretagogues. J. Clin. Endocrinol. Metab. 2012, 97, 37A. [CrossRef]

112. Garber, A.J. Long-acting glucagon-like peptide 1 receptor agonists: A review of their efficacy and tolerability. Diabetes Care 2011, 34, S279-S284. [CrossRef]

113. Filippatos, T.D.; Panagiotopoulou, T.V.; Elisaf, M.S. Adverse Effects of GLP-1 Receptor Agonists. Rev. Diabet. Stud. 2014, 11, 202-230. [CrossRef] 
114. Kalra, S.; Bhutani, J.; Mohan, V.; Unnikrishnan, R.; Kunju, P. Alpha-glucosidase inhibitors. Diabetol. Type 2 Diabetes Mellit. 2014, 64, 55. [CrossRef]

115. Hsia, D.S.; Grove, O.; Cefalu, W.T. An update on sodium-glucose co-transporter-2 inhibitors for the treatment of diabetes mellitus. Curr. Opin. Endocrinol. Diabetes Obes. 2016, 24, 1. [CrossRef]

116. Sebokova, E.; Christ, A.D.; Boehringer, M.; Mizrahi, J. Dipeptidyl peptidase iv inhibitors: The next generation of new promising therapies for the management of type 2 diabetes. Curr. Top. Med. Chem. 2007, 7, 547-555. [CrossRef]

117. Pathak, R.; Bridgeman, M.B. Dipeptidyl peptidase-4 (DPP-4) inhibitors in the management of diabetes. J. Formul. Manag. 2010, 35, 509-513.

118. Strack, T. Metformin: A review. Drugs Today 2008, 44, 303-314. [CrossRef] [PubMed]

119. Nanjan, M.; Mohammed, M.; Kumar, B.P.; Chandrasekar, M. Thiazolidinediones as antidiabetic agents: A critical review. Bioorganic Chem. 2018, 77, 548-567. [CrossRef] [PubMed]

120. Petrovski, G.; Zivkovic, M.; Milenkovic, T.; Ahmeti, I.; Bitovska, I. Successful desensitization in patient with type 2 diabetes with an insulin allergy using insulin pump and glargine. Acta Diabetol. 2014, 51, 1073-1075. [CrossRef] [PubMed]

121. Maehr, R.; Chen, S.; Snitow, M.; Ludwig, T.; Yagasaki, L.; Goland, R.; Leibel, R.L.; Melton, D.A. Generation of pluripotent stem cells from patients with type 1 diabetes. Proc. Natl. Acad. Sci. USA 2009, 106, 15768-15773. [CrossRef]

122. Abdi, R.; Fiorina, P.; Adra, C.N.; Atkinson, M.; Sayegh, M.H. Immunomodulation by mesenchymal stem cells: A potential therapeutic strategy for type 1 diabetes. Diabetes 2008, 57, 1759-1767. [CrossRef] [PubMed]

123. Spaggiari, G.M.; Abdelrazik, H.; Becchetti, F.; Moretta, L. MSCs inhibit monocyte-derived DC maturation and function by selectively interfering with the generation of immature DCs: Central role of MSC-derived prostaglandin E2. Blood 2009, 113, 6576-6583. [CrossRef]

124. Wu, J.; Sun, Z.; Sun, H.-S.; Wu, J.; Weisel, R.D.; Keating, A.; Li, Z.-H.; Feng, Z.-P.; Li, R.-K. Intravenously administered bone marrow cells migrate to damaged brain tissue and improve neural function in ischemic rats. Cell Transpl. 2007, 16, 993-1005. [CrossRef]

125. Tyndall, A.; Walker, A.U.; Cope, A.; Dazzi, F.; De Bari, C.; Fibbe, W.; Guiducci, S.; Jones, S.; Jorgensen, C.; Le Blanc, K.; et al. Immunomodulatory properties of mesenchymal stem cells: A review based on an interdisciplinary meeting held at the Kennedy Institute of Rheumatology Division, London, UK, 31 October 2005. Arthritis Res. Ther. 2007, 9, 301. [CrossRef]

126. Ianus, A.; Holz, G.G.; Theise, N.D.; Hussain, M.A. In vivo derivation of glucose-competent pancreatic endocrine cells from bone marrow without evidence of cell fusion. J. Clin. Investig. 2003, 111, 843-850. [CrossRef]

127. Ghannam, S.; Bouffi, C.; Djouad, F.; Jorgensen, C.; Noël, D. Immunosuppression by mesenchymal stem cells: Mechanisms and clinical applications. Stem Cell Res. Ther. 2010, 1, 1-7. [CrossRef] [PubMed]

128. Chien, K.R.; Moretti, A.; Laugwitz, K.-L. Development: ES cells to the rescue. Science 2004, 306, 239-240. [CrossRef] [PubMed]

129. Zalzman, M.; Gupta, S.; Giri, R.K.; Berkovich, I.; Sappal, B.S.; Karnieli, O.; Zern, M.A.; Fleischer, N.; Efrat, S. Reversal of hyperglycemia in mice by using human expandable insulin-producing cells differentiated from fetal liver progenitor cells. Proc. Natl. Acad. Sci. USA 2003, 100, 7253-7258. [CrossRef] [PubMed]

130. Meier, J.J.; Bhushan, A.; Butler, P.C. The potential for stem cell therapy in diabetes. Pediatr. Res. 2006, 59, 65R-73R. [CrossRef]

131. Zechmeister-Koss, I.; Huić, M. Vascular endothelial growth factor inhibitors (anti-VEGF) in the management of diabetic macular oedema: A systematic review. Br. J. Ophthalmol. 2011, 96, 167-178. [CrossRef]

132. Chao, E.C.; Henry, R.R. SGLT2 inhibition-A novel strategy for diabetes treatment. Nat. Rev. Drug Discov. 2010, 9, 551-559. [CrossRef]

133. Zhang, Q.; Shi, Y.; Wada, J.; Malakauskas, S.M.; Liu, M.; Ren, Y.; Du, C.; Duan, H.; Li, Y.; Li, Y.; et al. In vivo delivery of gremlin siRNA plasmid reveals therapeutic potential against diabetic nephropathy by recovering bone morphogenetic protein-7. PLoS ONE 2010, 5, e11709. [CrossRef]

134. Kato, M.; Natarajan, R. MicroRNAs in diabetic nephropathy: Functions, biomarkers, and therapeutic targets. Ann. N. Y. Acad. Sci. 2015, 1353, 72-88. [CrossRef]

135. Ledley, F.D. Pharmaceutical approach to somatic gene therapy. Pharm. Res. 1996, 13, 1595-1614. [CrossRef]

136. Gupta, N.; Mansoor, S.; Sharma, A.; Sapkal, A.; Sheth, J.; Falatoonzadeh, P.; Kuppermann, B.; Kenney, M. Diabetic retinopathy and VEGF. Open Ophthalmol. J. 2013, 7, 4-10. [CrossRef] [PubMed]

137. Randeria, P.S.; Seeger, M.A.; Wang, X.-Q.; Wilson, H.; Shipp, D.; Mirkin, C.A.; Paller, A.S. siRNA-based spherical nucleic acids reverse impaired wound healing in diabetic mice by ganglioside GM3 synthase knockdown. Proc. Natl. Acad. Sci. USA 2015, 112, 5573-5578. [CrossRef] [PubMed]

138. Thattet, U.M.; Dahanukar, S.A. Immunotherapeutic modification of experimental infections by Indian medicinal plants. Phytother. Res. 1989, 3, 43-49. [CrossRef]

139. Grover, J.; Yadav, S.; Vats, V. Medicinal plants of India with anti-diabetic potential. J. Ethnopharmacol. 2002, 81, 81-100. [CrossRef]

140. Pastors, J.G.; Warshaw, H.; Daly, A.; Franz, M.; Kulkarni, K. The evidence for the effectiveness of medical nutrition therapy in diabetes management. Diabetes Care 2002, 25, 608-613. [CrossRef]

141. Prasad, S.; Kulshresht, A.; Qureshi, T.N. Antidiabetic activity of some herbal plants in streptozotocin induced diabetic albino rats. Pak. J. Nutr. 2009, 8, 551-557. [CrossRef]

142. Bnouham, M.; Ziyyat, A.; Mekhfi, H.; Tahri, A.; Legssyer, A. Medicinal plants with potential antidiabetic activity-A review of ten years of herbal medicine research (1990-2000). Int. J. Diabetes Metab. 2006, 14, 1-25. [CrossRef] 
143. Jung, M.; Park, M.; Lee, H.C.; Kang, Y.-H.; Kang, E.S.; Kim, S.K. Antidiabetic agents from medicinal plants. Curr. Med. Chem. 2006, 13, 1203-1218. [CrossRef] [PubMed]

144. Muzzin, P.; Eisensmith, R.C.; Copeland, K.C.; Woo, S.L.C. Hepatic insulin gene expression as treatment for type 1 diabetes mellitus in rats. Mol. Endocrinol. 1997, 11, 833-837. [CrossRef]

145. Auricchio, A.; Gao, G.-P.; Yu, Q.; Raper, S.; Rivera, V.; Clackson, T.; Wilson, J. Constitutive and regulated expression of processed insulin following in vivo hepatic gene transfer. Gene Ther. 2002, 9, 963-971. [CrossRef] [PubMed]

146. Short, D.K.; Okada, S.; Yamauchi, K.; Pessin, J.E. Adenovirus-mediated transfer of a modified human proinsulin gene reverses hyperglycemia in diabetic mice. Am. J. Physiol. Metab. 1998, 275, E748-E756. [CrossRef]

147. O'Doherty, R.M.; Lehman, D.L.; Telemaque-Potts, S.; Newgard, C.B. Metabolic impact of glucokinase overexpression in liver: Lowering of blood glucose in fed rats is accompanied by hyperlipidemia. Diabetes 1999, 48, 2022-2027. [CrossRef]

148. Morral, N.; McEvoy, R.; Dong, H.; Meseck, M.; Altomonte, J.; Thung, S.; Woo, S.L. Adenovirus-mediated expression of glucokinase in the liver as an adjuvant treatment for type 1 diabetes. Hum. Gene Ther. 2002, 13, 1561-1570. [CrossRef] [PubMed]

149. O'Doherty, R.M.; Jensen, P.B.; Anderson, P.; Jones, J.G.; Berman, H.K.; Kearney, D.; Newgard, C.B. Activation of direct and indirect pathways of glycogen synthesis by hepatic overexpression of protein targeting to glycogen. J. Clin. Investig. 2000, 105, 479-488. [CrossRef] [PubMed]

150. Inzucchi, S.E.; Lipska, K.J.; Mayo, H.; Bailey, C.J.; McGuire, D.K. Metformin in patients with type 2 diabetes and kidney disease. JAMA 2014, 312, 2668-2675. [CrossRef] [PubMed] 